\title{
Socio-economic status and extent of adoption of climate resilient technologies in the Eastern Plain Zone of Uttar Pradesh
}

\author{
S. R. Devegowda*, Saket Kushwaha ${ }^{1}$ and P. S. Badal \\ Department of Agricultural Economics, Banaras Hindu University, Varanasi (U.P.) India \\ (Email: Devegowda.sr10@bhu.ac.in)
}

\begin{abstract}
The study focused on extent of adoption of climate resilient technologies and socioeconomic status of the farmers in the eastern plain zone of Uttar Pradesh. Data collected from flood and usar affected blocks of Varanasi and Chandauli subjected to analysis. High adoption of climate resilient technologies noticed followed by low and medium adoption. Farmers belonged to middle age and young age adopted climate resilient technologies more compare to old age farmers. Illiterates adopted less compare primary and secondary educated farmers, where they adopted more. Nuclear family constituted more in high and low adoption groups similar pattern followed in joint family. Among all groups of adoption, the medium family size accounted for the most adoptions, followed by the medium and big family sizes. Low income was predominant among farmers of all groups whereas high adopted farmers had higher income than medium and low adopted farmers. The majority of the farmers had medium farming experience, which affected positively on adoption more than high and low experience, low adopted farmers having less expertise. Farmers with a high extension contact used more climate resilient technology.
\end{abstract}

Key Words : Climate resilient technologies, Adoption, Flood, Usar, Socioeconomic status

View Point Article : Devegowda, S. R., Kushwaha, Saket and Badal, P. S. (2021). Socio-economic status and extent of adoption of climate resilient technologies in the Eastern Plain Zone of Uttar Pradesh. Internat. J. agric. Sci., 17 (AAEBSSD) : 281-286, DOI:10.15740/HAS/ IJAS/17-AAEBSSD/281-286. Copyright@2021: Hind Agri-Horticultural Society.

Article History : Received : 01.08.2021; Accepted : 03.08.2021

\section{INTRODUCTION}

The climatic factor is one of the important factors for crop production. Crop productivity is harmed by erratic rainfall and temperature fluctuations. In the absence of farmer adaptation, crop yields would decrease by 4.5-9 percent in the medium term and by a staggering 25 percent in the long run as a result of climate change. By 2100 , cereal productivity is anticipated to decline by $10-$
$40 \%$, with a larger decline in Rabi. Greater warmth, increased water stress, and a reduction in the number of rainy days have already had a detrimental impact on wheat and rice yields in areas of India (Devegowda et al., 2019; Guiteras, 2009 and Mahato, 2014).

Uttar Pradesh is India's most populated state and the country's largest agricultural producer. UP gets about $89 \%$ of its annual rainfall in the southwest monsoon 
season, noticed floods in the eastern districts of Uttar Pradesh (Khatoon, 1988). About 75894 ha area of eastern plain zone of Uttar Pradesh usar affected.

In this paper an attempt analyzed has been made to know the socio-economic condition and extent of adoption of climate resilient technologies with different level adoption in rice-wheat cropping system.

\section{Material AND Methods}

The present study was conducted in the eastern plain zone of Uttar Pradesh. Data collected as a purposive sampling from the flood affected blocks of Varanasi and Chandauli. The sample size of 240 was randomly collected from rice-wheat cropping farm households using a structured schedule. The data collected were subjected to descriptive statistical analysis such as frequency and percentage method using different scales.

Extent of adoption of climate resilient technologies calculated by collecting data from farmers who adopted climate technologies scored as one and one who do not have adopted the technologies scored as zero. In such a manner, the adoption score for all recommended technologies for an individual farmer was worked out. Then calculated the number of technologies adopted by each sample farmer. The mean and standard deviation are worked out for total number of technologies adopted by all the sample farmers. Classification of the farmers into low, medium and high adopters using following formula.

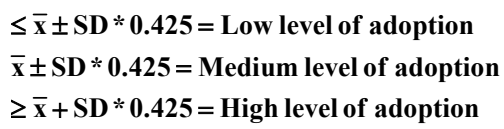

\section{Results AND Discussion}

The results obtained from the present investigation as well as relevant discussion have been summarized under following heads :

Extent of adoption of climate resilient technologies:

The data pertaining to adoption of climate resilient technologies in the rice and wheat cropping system were presented in the Table 1 revealed that the technologies adopted were usar resistant varieties and flood resistant varieties in rice, usar resistant varieties and terminal heat resistant varieties in wheat. From the total sample of 240 households, majority 114 farmers were found in high adopter category which accounted about 47.50 per cent, followed by 96 farmers from low adopter category that was 40 per cent and 30 farmers from medium adopter category that accounted about 12.50 per cent. Results obtained are in conformity with the findings of Kumar and Sidana (2017); Dika (2018) and Madan Kumar (2019). Contrary results found in Chouhan et al. (2016); Manjunath et al. (2018) and Oraon et al. (2018).

\section{Distribution of the farmers according to their age:}

Physical and psychological development of an individual depends on age. categorized into three categories viz., (i) Young age (upto 34 years), (ii) Middle age (35 to 54 years) and (iii) Old age (above 54 years). Data in the from Table 2 revealed that among total farmers 65.42 per cent farmers belongs to middle age category, 25 per cent of the farmers belongs to old age category and 9.58 per cent of the farmers in young age category. Similar pattern followed in low, medium and high adopted groups. In general, it is cleared from the data that majority of the farmers $(65.42 \%)$ were in middle age category. Thus, it indicated that they have enough maturity and have interest to take any decision to do better for their family, considering the best course of action available. Similar results found Siddayya et al. (2016) and Sharma et al. (2018) Contrary result found Afolabi (2010).

\section{Distribution of the farmers according to their education:}

Education was operationalized as formal education received by the farmers. The data in this regard were collected and score were assigned as suggested by the SES scale developed by Pandya (2010). Education categories classified into (i) Illiterate, (ii) Primary

\begin{tabular}{llcc}
\hline \multicolumn{2}{l}{ Table 1: Distribution of farmers according to their adoption level of climate resilient technologies } & \\
\hline Sr. No. & Level of adoption & No. of sample farmers & Per cent \\
\hline 1. & High (mean $+0.425 * \mathrm{SD})$ & 114 & 47.5 \\
2. & Medium (mean $\pm 0.425 * \mathrm{SD})$ & 30 & 12.5 \\
3. & Low (mean-0.425*SD) & 96 & 40 \\
& Total & 240 & 100 \\
\hline
\end{tabular}


education, (iii) Secondary education and (iii) College and above. Table 2 showed that majority of the farmers were primary education holders constitute about 35.83 per cent of primary education holders and 35.42 per cent of illiterates. Secondary education holder were about 14.17 per cent and 14.58 per cent farmers were college and above education. Primary educated farmers contributed 34.21 per cent to the high adoption group and they were 16.25 per cent to total farmers. Majority of high adopted farmers belongs to primary education whereas medium and low adopted farmers were illiterates.

This it can be said that majority adopted farmers had more primary and secondary education and low adopted farmers had illiterate and primary education. Results were in line with Siddayya et al. (2016) and
Thinde et al. (2017). Contrary result found in Mohokar et al. (2019).

\section{Distribution of the farmers according to their type of family:}

Family classified into two broad categories (i) Joint and (ii) Nuclear. Table 2 revealed that about 60.83 per cent of the farmers were nuclear family and 39.17 per cent farmers in joint family for total farmers group. Same pattern for high, medium and low adopter groups also. Generally majority of families belongs to nuclear family and nuclear family were adopted more of climate resilient technologies in comparison with the joint families. Similar results found in Brunda (2018). Contrary results found in Ali, Beshir Issa and Rahut (2020).

\begin{tabular}{|c|c|c|c|c|c|c|c|c|c|c|c|c|}
\hline \multirow{2}{*}{$\begin{array}{l}\text { Socio- } \\
\text { economic } \\
\text { characteristics }\end{array}$} & \multirow{2}{*}{ Categories } & \multicolumn{2}{|c|}{$\begin{array}{l}\text { Total farmers } \\
(\mathrm{n}=240)\end{array}$} & \multicolumn{3}{|c|}{$\begin{array}{l}\text { High adoption } \\
(\mathrm{n}=114)\end{array}$} & \multicolumn{3}{|c|}{$\begin{array}{c}\text { Medium adoption } \\
(\mathrm{n}=30)\end{array}$} & \multicolumn{3}{|c|}{$\begin{array}{c}\text { Low adoption } \\
(\mathrm{n}=96)\end{array}$} \\
\hline & & FQ & $\%$ & FQ & $\%$ & $\begin{array}{c}\text { Overall } \\
\%\end{array}$ & FQ & $\%$ & Overall \% & FQ & $\%$ & Overall \% \\
\hline \multirow{3}{*}{ Age } & Young & 23 & 9.58 & 8 & 7.02 & 3.33 & 2 & 6.67 & 0.83 & 13 & 13.54 & 5.42 \\
\hline & Middle & 157 & 65.42 & 86 & 75.44 & 35.83 & 17 & 56.67 & 7.08 & 54 & 56.25 & 22.5 \\
\hline & Old & 60 & 25 & 20 & 17.54 & 8.33 & 11 & 36.67 & 4.58 & 29 & 30.21 & 12.08 \\
\hline \multirow{4}{*}{ Education } & Illiterate & 85 & 35.42 & 17 & 14.91 & 7.08 & 16 & 53.33 & 6.67 & 52 & 54.17 & 21.67 \\
\hline & Primary & 86 & 35.83 & 39 & 34.21 & 16.25 & 9 & 30 & 3.75 & 38 & 39.58 & 15.83 \\
\hline & Secondary & 34 & 14.17 & 30 & 26.32 & 12.5 & 1 & 3.33 & 0.42 & 3 & 3.13 & 1.25 \\
\hline & College and above & 35 & 14.58 & 28 & 24.56 & 11.67 & 4 & 13.33 & 1.67 & 3 & 3.13 & 1.25 \\
\hline \multirow{2}{*}{$\begin{array}{l}\text { Type of } \\
\text { family }\end{array}$} & Joint & 94 & 39.17 & 45 & 39.47 & 18.75 & 12 & 40 & 5 & 37 & 38.54 & 15.42 \\
\hline & Nuclear & 146 & 60.83 & 69 & 60.53 & 28.75 & 18 & 60 & 7.5 & 59 & 61.46 & 24.58 \\
\hline \multirow{3}{*}{ Family size } & Small family & 0 & 0 & 0 & 0 & 0 & 0 & 0 & 0 & 0 & 0 & 0 \\
\hline & Medium family & 160 & 66.67 & 76 & 66.67 & 31.67 & 18 & 60 & 7.5 & 66 & 68.75 & 27.5 \\
\hline & Big family & 80 & 33.33 & 38 & 33.33 & 15.83 & 12 & 40 & 5 & 30 & 31.25 & 12.5 \\
\hline \multirow{3}{*}{$\begin{array}{l}\text { Annual } \\
\text { income }\end{array}$} & LAI & 226 & 94.17 & 100 & 87.72 & 41.67 & 30 & 100 & 12.5 & 96 & 100 & 40 \\
\hline & MAI & 14 & 5.83 & 14 & 12.28 & 5.83 & 0 & 0 & 0 & 0 & 0 & 0 \\
\hline & HAI & 0 & 0 & 0 & 0 & 0 & 0 & 0 & 0 & 0 & 0 & 0 \\
\hline \multirow{5}{*}{ Land holding } & Marginal & 145 & 60.42 & 52 & 45.61 & 22 & 20 & 66.67 & 8.33 & 73 & 76.04 & 30.41 \\
\hline & Small & 74 & 30.83 & 47 & 41.23 & 20 & 7 & 23 & 2.91 & 20 & 20.83 & 8.33 \\
\hline & Semi-Medium & 20 & 8.33 & 15 & 13 & 6.25 & 2 & 6.67 & 0.83 & 3 & 3.13 & 1.25 \\
\hline & Medium & 1 & 0.42 & 0 & 0 & 0 & 1 & 3.33 & 0.41 & 0 & 0 & 0 \\
\hline & Large & 0 & 0 & 0 & 0 & 0 & 0 & 0 & 0 & 0 & 0 & 0 \\
\hline \multirow{3}{*}{$\begin{array}{l}\text { Farming } \\
\text { experience }\end{array}$} & Low & 37 & 15.42 & 16 & 14.04 & 6.67 & 4 & 13.33 & 1.67 & 18 & 18.75 & 7.5 \\
\hline & Medium & 156 & 65 & 77 & 67.54 & 32.08 & 18 & 60 & 7.5 & 62 & 64.58 & 25.83 \\
\hline & High & 47 & 19.58 & 21 & 18.42 & 8.75 & 8 & 26.67 & 3.33 & 16 & 16.67 & 6.67 \\
\hline \multirow{3}{*}{$\begin{array}{l}\text { Extension } \\
\text { contact }\end{array}$} & Low & 96 & 40 & 40 & 33.33 & 15.83 & 13 & 43.33 & 5.42 & 45 & 46.88 & 18.75 \\
\hline & Medium & 106 & 44 & 44 & 39 & 18 & 0 & 0 & 0 & 0 & 0 & 0 \\
\hline & High & 38 & 15.83 & 16 & 28.07 & 13.33 & 17 & 56.67 & 7.08 & 51 & 53.13 & 21.25 \\
\hline
\end{tabular}

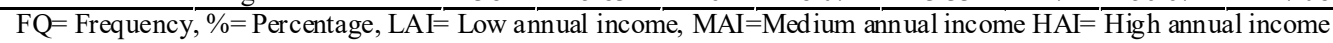




\section{Distribution of the farmers according to their family} size:

Family size was a total number of members in the family of farmers. The size of family was measured with the help of SES scale developed by Pandya (2010), where family size classified into three categories (i) Small family (upto 2), (ii) Medium family (3 to 8) and (iii) Big family (More than 8). According to the Table 2 most of the families were medium family followed by big and small families. About 66.67 per cent of households were medium size family, 33.33 per cent of households were big family size and small families not found in the study. Small families did not exist among all the groups but more number of families belonged to medium category followed by big family, respectively.

Medium families adopted more climate resilient technologies in caparison to big families. Medium families also showed high adoption rate than the big families in the results. Similar results found Chauhan, (2016), contrary results found in Brunda, (2018) and Kumar et al. (2020).

\section{Distribution of the farmers according to their annual income:}

The income availed from different sources by an individual and their family member throughout the year was called as an annual income. It has been considered as a major economic factor by several researchers therefore, it was incorporated in present study. The data in this regard were collected and grouped into three categories (i) Low annual income (upto Rs. 50,000/-), (ii) Medium annual income (Rs. 50,001 to 1,00,000/-) and (iii) High annual income (above Rs. 1,00, 000/-). The data presented in the Table 2 predominant farmers belongs to low annual income $(94.17 \%)$ category followed by medium (5.83\%) and high annual income category in the total farmer group. Medium income farmers found only in high adopted group whereas all the farmers in the medium and low adopted group belonged to low income group. Results found that farmers belong to low income group followed by medium income and high income group. Comparatively more income farmers adopted climate resilient technology with respect to less income category. Similar results found in Chauhan, (2016), but contrary Mohokar et al. (2019).

\section{Distribution of the farmers according to their land holding:}

Land type and its size is an important factor in agriculture that determines the potentiality of a farmer in adoption of new techniques and technology for management classified into five categories viz., (i) Marginal land holding (below 1.00 ha), (ii) Small land holding (1.00 to $1.99 \mathrm{ha}$ ), (iii) Semi-medium land holding (above 2.00 to 3.99 ha), (iv) Medium land holding (4.00 to $9.99 \mathrm{ha}$ ) and (v) Large land holding (10.00 and above). This variable referred to the total area owned by the rice- wheat cropped farmers at the time of interview. It is evident from Table 2 that majority of the farmers were marginal $(60.42 \%)$ followed by small $(30.83 \%)$, semi medium $(8.33 \%)$, medium $(0.42 \%)$ farmers found in the study, more number of marginal farmers found in low and medium adoption group whereas even though marginal farmers high in high adopted group difference between marginal and small farmers narrow.

Generally marginal farmers were found more in the study; marginal farmers were more in low adoption capacity majorly they belongs to low adoption group. Small and medium farmers adopted more of climate resilient technologies. Results obtained are in conformity with the findings of Thinde et al. (2017). Contrary results found in Dhayal and Mehta (2015).

\section{Distribution of the farmers according to their farming experience :}

Experience is nothing but an individual involvement in enterprise. The data in this regard were collected and scores were assigned as suggested in the scale developed by the Silvakumar (1988). The respondents were categorized as (i) Low farming experience (upto 8 year), medium farming experience ( 9 to 15 year) and high farming experience (above 15 year). According to Table 2 about two third of the farmers belonged to medium experienced, 19.58 per cent farmers were high experience and 15.42 per cent of the farmers low experience in crop production. High adopted and medium adopted farmers majorly were medium experienced followed by high and low experienced, respectively but in low adoption group medium experienced subsequently by low and high adoption.

Generally medium experienced farmers found more in the study among all the categories. High and medium adoption groups high experienced found more than the low experienced farmers but in the low adoption group low experienced farmers found compare to other two groups. That showed medium experienced farmers adopted more of climate resilient technologies followed 
Socio-economic status \& extent of adoption of climate resilient technologies

by high and low experienced. Results were confirmatory with Chauhan (2016); Mohokar et al. (2019) and Kumar et al. (2020).

\section{Distribution of the farmers according to their extension contact:}

Extension contact is an important factor in agriculture that determines the potentiality of a farmer in adoption of new techniques and technology for management in their farm. The procedure followed by Hiremath (2000) was used with slight modifications into three categories (i) Low, (ii) Medium and (iii) High. Table 2 explained majority of the farmers belonged to medium extension contact that was 44 per cent, 40 per cent of low extension contact and 15.83 per cent of high extension contact. In the high adoption group more number of farmers belongs to medium extension contact subsequently by low and high extension contact but in low and medium and high adoption group medium extension contact was absent, high extension contact followed by low extension contact where the gap between both the categories was narrow.

As an overall majority of the farmers belonged to medium and high extension contact adopted the climate resilient technologies some farmers even though more extension contact not adapted due to other factors. Similar results found in line with Ayanwuyi, (2013) and Mohokar et al. (2019).

\section{Conclusion:}

Results showed for climate resilient technology adoption in rice-wheat system. Farmers' were belonged to high adoption subsequently by low and medium adoption respectively. Majority of farmers belonged to middle age and young age adopted climate resilient technologies more compare to old age farmers. Primary and secondary educated farmers adopted more whereas illiterates' adopted less. Nuclear family constituted more in high and low adoption groups followed by joint family. Medium family size constituted more among all categories of adoption and then medium and big family adopted more. Low income was predominant among farmers of all groups whereas high adopted farmers' income more compare to medium and low adoption. Majority of the farmers were medium farming experience that influenced more of adoption subsequently by high experience and low experience, low adopted farmers were less experienced. High extension contact farmers adopted more of climate resilient technologies.

\section{REFERENCES}

Afolabi, J. A. (2010). Analysis of loan repayment among small scale farmers in Oyo State, Nigeria. Journal of Social Sciences, 22(2): 115-119.

Ali, A., Beshir Issa, A. and Rahut, D. B. (2020). Adoption and Impact of the Maize Hybrid on the Livelihood of the Maize Growers: Some Policy Insights from Pakistan. Scientifica, 2020: $1-8$.

Ayanwuyi, E. (2013). Extension Services Strategies in Adaptation to Climate Change in Oyo State, Nigeria. Civil \&Environmental Research, 3(7): 115-120.

Brunda, S. (2018). Economic Impact of Bengalgram Technologies Developed By UAS, Raichur in Nek Region, M. Sc. (Ag.) Thesis, University of Agricultural Sciences, Raichur.

Chauhan, G. (2016). Entrepreneurial Ability of Cashew Nut Growers of Tribal Region of South Gujarat. Ph. D. (Ag.) Thesis, Navsari Agricultural University. Navsari (Gujarat) India.

Devegowda, S R., Kushwaha, S., Kumari, K. and Pavan, M. K. (2019). The Impact of Climate Change on Indian Agriculture. In Research Trends in Agriculture Sciences, 16:41-55.

Dhayal, B. L. and Mehta, B. M.(2015). Study on knowledge and adoption of green gram production technology by farmers in Chhotaudaipur district of Gujarat. Agriculture Update, 10(4): 318-322.

Dika, G. (2018). Impacts of climate variability and households adaptation strategies in Lare district of Gambella Region, South Western Ethiopia. Journal of Earth Science and Climate Change, 9(480): 1-12.

Guiteras, R. (2009). The impact of climate change on Indian Agriculture. Maryland.

Hiremath, N. S. (2000). Participation of rural youth in farm and non-farm activities. M.Sc. (Ag.) Thesis, University of Agricultural Sciences, Dharwad.

Khatoon, R. (1988). Floods in Uttar Pradesh a Geographical Perspective. Aligarh Muslim University, Aligarh.

Kumar, A., Takeshima, H., Thapa, G., Adhikari, N., Saroj, S., Karkee, M. and Joshi, P. K. (2020). Adoption and diffusion of improved technologies and production practices in agriculture: Insights from a donor-led intervention in Nepal. Land Use Policy, 95(2020): 1-14.

Kumar, S. and Sidana, B. K. (2017). Enhancing Farmers' Income through Climate Resilient Technologies. Indian Journal of Economics \& Development, 13(4): 609-613.

Madan Kumar, K. P. (2019). Impact of Climate Resilient 
Technologies on Crop Production in Rayalaseema Region of Andhra Pradesh. Indian Agricultural Research Institute, New Delhi.

Mahato, A. (2014). Climate Change and its Impact on Agriculture. International Journal of Scientific and Research Publications, 4(4): 1-6.

Manjunath, K. V., Shivaramu, K. and Suresh, D. K. (2018). Adoption of Climate Resilient Technologies by Paddy Growers.Asian Journal of Agricultural Extension, Economics \& Sociology, 28(3): 1-9.

Mohokar, S. D., Gohad, V. V., Ingawale, P. A. and Holkar, V. V. (2019). Impact of national innovations on climate resilient agriculture (NICRA) project on beneficiaries. Agriculture Update, 14(3): 220-223.

Oraon, D., Singh, R. K., Pandey, V. K., Rai, V. P., Singh, U. K. and Alam, Z. (2018). Extent of adoption of climate resilient technologies in adopted Villages of Chatra District in Jharkhand. Journal of Krishi Vigyan, 7(1): 124-128.

Pandya, C. D. (2010). A Critical Analysis of Soico-Economic Status of Organic Farming Followers of South Gujarat. Ph.D. Thesis, NAU, Navsari Campus.
Sharma, S., Kumar, R., Kumar, M., Gupta, S., Maurya, P. K. and Singh, P. (2018). A study on socio-economic status of fishermen of Amethi district, Uttar Pradesh, India. International Journal of Fisheries and Aquatic Studies, 6(4): 49-54.

Siddayya., Dandekar, A. K. and Kammar, K. S. (2016). Adoption pattern of improved pigeon pea varieties in Kalaburagi district, Karnataka, India. Agricultuarl Science Digest, 36(4):255-260.

Silvakumar, B. (1988). Information support utilization for awareness, conviction and adoption of cotton whitefly control measures by contact and non contact farmers. M.Sc. (Ag.) Thesis, Tamil Nadu Agricultural University, Coimbatore (T.N.) India.

Thinde, L. K., Sai, A. K., Parmar, K., Hembram, D., Pal, D. and Kushwaha, R. K. (2017). Socio-economic characteristics of wheat growers regarding adoption of improved wheat production technology in Kanpur Dehat district, Uttar Pradesh (India). International Journal of Current Microbiology and Applied Sciences, 6 (12) : 2319-7706. 